Revista Iberoamericana, Vol. LXXVII, Núms. 236-237, Julio-Diciembre 2011, 749-768

\title{
VÍNCULOS DE PODER Y SABER: SOR JUANA Y EL ESPEJO MÁGICO DEL NEPTUNO
}

\author{
POR \\ Álvaro Llosa SANZ \\ University of California, Davis
}

Sor Juana Inés de la Cruz presenta su primera gran obra de erudición ante el público en 1680: el Neptuno alegórico, océano de colores, simulacro político... Es un texto que describe y justifica el programa iconográfico elaborado en el arco triunfal erigido a costas del Cabildo ante la entrada catedralicia en la Ciudad Imperial de México, para la entrada el treinta de noviembre del mismo año del virrey Tomás Antonio de la Cerda y Aragón, Conde de Paredes y Marqués de la Laguna. A dicho arco acompañó otro costeado por la ciudad y realizado por don Carlos Sigüenza y Góngora. ${ }^{1}$

Este texto es el testimonio escrito de un arco triunfal que se ofrecía a mayor gloria del virrey como elaboración de arquitectura efímera en el marco urbano de la exuberante fiesta barroca, acontecimiento que venía celebrándose en la ciudad ante la entrada de autoridades ya desde el año $1528 .{ }^{2}$ Si bien en ocasiones, y para dar cuenta a la posteridad, se encargaban relaciones a intelectuales que observaron el acontecimiento del boato urbano vivido en el día con su grandioso desfile y sucesión de arquitectura efímera (López Poza 248), el caso del Neptuno es una relación de otro tipo elaborada por la propia autora sobre el programa iconográfico del arco en sí -el último de los diseños del día, pero no el único-, donde se justifican al mismo tiempo que se describen y explican los lienzos y elementos incluidos en él. ${ }^{3}$ La única noticia que filtra sor Juana sobre el

1 Era un arco anterior en el desfile en el que ingeniosamente se comparaba al virrey con grandes emperadores aztecas. Liga su tema al de sor Juana justificando que Neptuno es bisnieto de Noé y progenitor de los indios occidentales (Sabat de Rivers 65). Véase el artículo de Catalá donde se detalla la naturaleza de esta genealogía. Para una comparación de ambos arcos, véase Checa (280-305), quien los trata especialmente como vehículos de la imagen del poder virreinal, o también Paz (203-28).

2 México competía con la metrópoli y brillaba en sus fiestas como ciudad imperial. La fecha de 1528 la da Sigúenza y Góngora en la explicación de su propio arco (Sabat de Rivers 63). Un buen resumen de los antecedentes y descripción completa del desarrollo de estas ceremonias puede verse en López Poza (241-45). Sobre la ceremonia, el arco y textos de Sigüenza y el de sor Juana, véase Paz (193-228).

3 De hecho, no puede decirse que sea una relación estrictamente, ya que el objetivo del texto es explicitar todo un plan erudito para comprender el sentido profundo -y subversivo para el lector atento- que encierran e implican las estampas simbólicas del arco más que relatar los acontecimientos del día y 
efecto en el público es la siguiente, tras explicar brevemente el montaje de las piezas:

En cuya montea se dio lugar a los ochos tableros, en que se copiaron las empresas y virtudes del dios Neptuno; ideándose en ellas algunos de los innumerables elogios, que así por su real ascendencia, como por sus altas proezas e incomparables prendas, se ha merecido el Excelentísimo Señor Marqués de la Laguna; ostentando el Arco en los colores, en lo perfecto de las líneas, en los resplandores del oro que lo pulía a rayos, no ser menos que fábrica consagrada a tanto príncipe; llevándose sus inscripciones la atención de los entendidos, como sus colores los ojos de los vulgares; y el cordial amor y el respeto de todos, los dos retratos de Sus Excelencias, en señal del que tiene a sus perfectos originales, que el Cielo guarde para que gocemos en ejecuciones los felices anuncios de su gobierno. (115)

El arco en sí, obra conceptual emblemática, visual y verbal al mismo tiempo, busca impresionar a todo tipo de público, ya que la sociedad por completo -presos y prostitutas incluidos-se daba cita carnavalesca en estas festividades (Sabat de Rivers 63). Las imágenes y sus colores quedan para fascinar al vulgo inculto, y la élite intelectual podía discurrir entre los epigramas y motes que rubricaban las imágenes. El objetivo de tanto esfuerzo concentrado en un arco era, al mismo tiempo que halagar al virrey, buscar la exaltación social de la autoridad representada en la figura del virrey mismo.

En el presente artículo veremos cómo sor Juana, superando la mera alabanza monárquica, pretende igualarse a la autoridad virreinal otorgándose una elevada autoridad erudita que busca la legitimación personal para poder dar consejos al virrey mismo, proponiendo desde un papel de mujer sabia la exposición de un espejo político cuyo reflejo idealizado y manipulado por sor Juana le sirva de modelo a seguir al virrey. Para ello afiliará la creación de su texto a una serie de técnicas retóricas ligadas a la fantasía y al ejercicio hermético de las imágenes simbólicas en el Barroco, de tal modo que, mediante las estrechas relaciones establecidas entre ellas -y funcionando en conjunto a modo de poderoso talismán intelectual revelado-, pueda no sólo atraer y convencer, sino directamente vincular o atrapar al virrey en un muy personal proyecto civilizador.

Para empezar, debe recalcarse que el Neptuno redactado por sor Juana e impreso después de la festividad va dirigido expresamente al virrey, y su lectura se limita a la élite intelectual. ${ }^{4}$ Está dividido en una carta dedicatoria, una razón de la fábrica alegórica

realizar una descripción más o menos erudita del tema iconográfico: "No es el Neptuno alegórico, estrictamente, una 'relación festiva', sino una especie de libreto, guión o plan para el arco triunfal que se iba a construir e instalar en la puerta occidental de la catedral, [...] Es un programa y una lección política alegorizada llena de ingenio gracianesco" (Arenal, Introducción 20).

4 "Los humanistas encargados de imaginar el programa simbólico que daría cuerpo y alma a una de esas efímeras fábricas celebratorias, habían de comenzar por redactar un programa alegórico del que se exponían las motivaciones eruditas y las argumentaciones analógicas que hicieran plausible la representación de las virtudes de un príncipe cristiano por medio de una fábula de la Gentilidad. Ese

Revista Iberoamericana, Vol. LXXVII, Núms. 236-237, Julio-Diciembre 2011, 749-768 ISSN 0034-9631 (Impreso) 
y la aplicación de la fábula, añadiéndose al final los poemas relativos a los ocho lienzos principales que seguramente constituyeron la loa leída ante el arco, el virrey y la ciudad de México aquel treinta de noviembre. ${ }^{5}$ La crítica ha destacado en varias ocasiones que este texto, además del habitual panegírico al virrey comparándolo con algún personaje elevado de la antigüedad -con lo que se elaboraba a menudo un speculum principis o espejo de príncipes-, sor Juana incluye asimismo algunas peticiones explícitas ante el mandatario: una canalización definitiva de la laguna sobre la que se asienta México, la terminación del edificio de la catedral, y un clima de estabilidad y paz en el virreinato (López Poza 258; Boyer 38; Pascual Buxó 143-44). Estas peticiones que sor Juana realiza como portavoz ciudadana para dichos asuntos de ámbito civil, religioso y social tenían su origen en verdaderos problemas que llevaban años sin resolverse y que urgían arreglo. ${ }^{6}$ Así, el Neptuno adquiere un explícito carácter de función política sobre el habitual encomiástico (Pascual Buxó 148).

Es interesante en este punto preguntarse quétécnica y autoridad-como programadora ideológica- le permiten a sor Juana con tanta naturalidad -y como culminación a una trama de gran sutileza-incluir las peticiones en su discurso ante un virrey; vamos a ver que hay todo un arte del concepto retórico por encadenación de imágenes que permite a sor Juana ir un poco más allá de lo ortodoxo al amparo de su fantasía; y con él pretender vincular de tal manera la figura del virrey al simulacro conceptual que ella propone, que el político no pueda ver más que naturales las proposiciones de sor Juana como propias de su naturaleza y misión. Debemos valorar que si sor Juana da una función política a su Neptuno, es porque sencillamente la monja aspira, según un ideario -personal o no-, a transformar su inmediato universo novohispano utilizando al virrey como principal instrumento capaz de llevar a cabo la tarea.

Voy a recuperar para esto un concepto elaborado por el dominico Giordano Bruno (1548-1600) a finales del siglo xvı, que él deriva de toda una teoría universal del pensamiento neoplatónico popularizada por Marsilio Ficino a finales del siglo XV, transmitida a través de los filósofos del Renacimiento y que influyó enormemente en

discurso preliminar, del que habían de partir arquitectos y pintores para el cumplimiento de su obra, serviría - una vez publicada la relación de festejo- para el deleite intelectual de quienes supieran apreciar la ingeniosa elegancia con que el autor supo disponer de las fuentes eruditas y doctrinales en que se abrevaba su fabulosa máquina laudatoria” (Pascual Buxó 113).

5 Sabat de Rivers no entiende estos poemas de la loa como cuerpo del Neptuno, por pertenecer a la representación del acto festivo y no a la memoria escrita propiamente (69). Boyer piensa lo contrario, porque completan todo un diseño polimétrico (40-41).

6 La canalización de la laguna mexicana tiene una larga y tortuosa historia, como puede apreciarse en el volumen de Rodríguez-Sala. La catedral había sido inaugurada unas décadas antes, pero sin las torres (de la Cruz, Obras IV 620), y los movimientos insurgentes eran habituales en la época del virreinato, de grandes inestabilidades. Las citas del Neptuno de sor Juana se realizan por la paginación según la edición reciente de Vincent Martin, y el resto de textos de las Obras completas.

$\begin{array}{lllll}\text { ISSN 2154-4794 (Electrónico) } & \text { Revista Iberoamericana, Vol. LXXVII, Núms. 236-237, Julio-Diciembre 2011, 749-768 }\end{array}$ 
toda la cosmovisión renacentista de las artes y las ciencias, hasta llegar a Athanasius Kircher (1601-1680). ${ }^{7}$ El concepto de vinculum se asocia a los lazos que unen los diversos elementos de que se compone el universo, tanto simples como complejos: hay multitud de vínculos por los cuales, por ejemplo, el imán atrae al hierro o el aceite rechaza el agua, en un juego de atracción y repulsión, amor y odio, que dinamiza y constituye el universo completo. Bruno elabora esta idea desde el mundo sensible hasta el mundo celeste y la extiende a la naturaleza humana hasta definir una suerte de sicología simpática entre los miembros de una sociedad, por lo que lo aplica igualmente como elemento clave de las relaciones civiles (Bruno 70). En este sentido, las diferentes funciones sociales implican toda una red de vínculos por la diferencia de riquezas, valores y objetivos, con lo que estas personas públicas asumen

[...] diferentes roles de la administración civil, donde obran como medios o instrumentos, lo cual les pone la cuestión de vincularlos a sí. No parece, en definitiva, que realidad alguna escape a una reflexión sobre las relaciones civiles desde esta perspectiva: en la medida en que los hombres vinculan o están bajo vínculos o son ellos mismos vínculos o circunstancias vinculantes. (Bruno 70) ${ }^{8}$

La situación ante la que se encuentra sor Juana tras la petición del Cabildo es inusitada: una monja de clausura, ${ }^{9}$ aunque conocida en la corte por su servicio de dama, por su afición al estudio y la creación poética, debe elaborar el programa iconográfico para dar la bienvenida al virrey en una gran fiesta pública. Constituye la primera gran oportunidad de sor Juana, mujer además, para mostrar en el espacio público masculino su erudición y conocimientos, su ingenio y su agudeza. ${ }^{10}$ Su entendimiento sale por vez primera del espacio privado del claustro al espacio público de la urbe. Debe alabar al virrey y además incluir unas peticiones -desconocemos si exclusivamente suyas o animadas por el Cabildo y otras instituciones-, para lo cual, según nuestro análisis bruniano, ella debe crear una adecuada vinculación entre sí -una atípica mujer religiosa de formación humanista autodidacta-y el virrey, a través de la cual establece la posición del virrey, la suya propia y la autoridad intermediaria con la que hace las peticiones.

7 El eslabón que Kircher supone en esta cadena que termina en el iluminismo del siglo xvIII lo refiere brevemente Paz (220-26, 238-39). Para una exposición completa del período está el libro de Yates, Giordano Bruno y la tradición hermética.

8 Transferido esto al interior del arco descrito en el Neptuno, a similaridad de las relaciones sociales fuera de él,“los emblemas de su fachada constituyen un código simbólico con el que se formulan relaciones sociales complejas” (Boyer 43).

9 Según Paz, escritora "sin estatuto definido” y “monja letrada sin padre conocido” (206).

10 "La capacidad de un autor para crear relaciones y establecer correspondencias, es decir, para crear conceptos, es lo que le dotaba de la cualidad de agudo, lo que en una época en que se estimaba mucho ese procedimiento, le proporcionaba admiración” (López Poza 246).

Revista Iberoamericana, Vol. LXXVII, Núms. 236-237, Julio-Diciembre 2011, 749-768 ISSN 0034-9631 (Impreso) 
Tarea no muy fácil al punto que en la captatio benevolentiae del Neptuno sor Juana imagina haber sido elegida porque, como mujer débil, atraerá más fácilmente el perdón del virrey (358). Pero no va a ser con debilidad como se dirija al virrey, y el vínculo que desea crear a través del Neptuno como vía de éxito para su intermediación pretende ser de una fuerza indestructible y busca invertir finalmente los términos de poder.

Dicho esto, debe señalarse ahora que la naturaleza técnica del arco que diseña entronca con toda una tradición emblemática de carácter simbólico ligada a la elaboración de conceptos, y se corresponde muy bien con el carácter vinculador que se atribuye a este tipo de artefactos artísticos, como lo demuestra en el contexto novohispano el desarrollo que los jesuitas le otorgan para atraer y enseñar a los indígenas la nueva fe. ${ }^{11}$ Según Bruno, "las puertas a través de las cuales el cazador de almas lanza sus vínculos son tres: la vista, el oído y la mente o imaginación. Si logra abrirse un paso por las tres puertas, vincula del modo más riguroso, estrecha sus lazos” (84-85). Así, mientras que el público general quedaba suspendido por las imágenes, y probablemente por la música de la fiesta y el ritmo de la loa, los más entendidos se veían ligados, además, a través de la mente. Y el Neptuno, como relación del arco dirigida al virrey, sin duda recurre por un lado a la memoria del mismo sobre el arco físico el día de la ceremonia, y a través de ese ejercicio de memoria, por la lectura en alta voz -pues en alta voz se leía entonces-, sor Juana accede a la puerta de la mente con toda su explicación erudita. La monja parece tener en cuenta que "es más fácil ligar a muchos que a uno" (Bruno 104), así que el esmero para atraer al virrey -y a cada miembro de la élite intelectual que acceda al documento- debe ser extremo, en especial porque "sabe vincular sólo aquel que penetra en la razón de todo; o al menos en la naturaleza, disposición, inclinación, aptitud, utilidad y finalidad de aquella realidad que debe ser vinculada” (75). Además, si se apela al intelecto, la vinculación debe ser por el juicio y la prudencia, "con razonamientos y demostraciones y símbolos y tratamientos convincentes” (89). Esto justificaría sobradamente, desde la teoría vinculatoria de Bruno, que sor Juana dedique una primera parte a justificar con precisión la naturaleza de la similitud entre el dios Neptuno y el virrey a través de los jeroglíficos. ${ }^{12}$ De hecho, su primer objetivo es aclarar el término y uso del jeroglífico, que califica de técnica egipcia para mostrar visiblemente lo invisible, es decir, a las deidades, para que estos jeroglíficos “por similitud, ya que no

${ }^{11}$ Como se deduce del artículo de Mariscal sobre los programas emblemáticos de los jesuitas para la entrada de reliquias en las ciudades, donde los indios participaban en el diseño iconográfico y se dirigía al público con clara intención práctica y dogmática. Para la capacidad simbólica de los emblemas y su desarrollo, y presencia en los siglos XVI y XVII en el ámbito español, véase el libro de Rodríguez de la Flor (Emblemas).

12 Pascual Buxó documenta la moda novohispana de los jeroglíficos en murales conventuales del siglo XVI en Meztitlán (105). Emblemática y neoplatonismo dotaron desde el siglo XVI de misterio simbólico a los jeroglíficos, que no eran vistos como "medios de representación de la realidad, sino la realidad misma” (Paz 221). Athanasius Kircher, elogiado y seguido en muchos aspectos por sor Juana, admiraba la escritura simbólica jeroglífica de la que parte el Neptuno, si bien con matices.

ISSN 0034-9631 (Impreso) 
por perfecta imagen, las representasen" (de la Cruz, Neptuno 66). Con esto, pretende separar, al menos teóricamente, la identificación absoluta entre imagen y representación, eliminando con ello una trascendencia o conexión absoluta entre ambos que pudiera acusarla de brujería o heterodoxia. Ciertamente, “de entrada niega sor Juana el carácter óntico -o hermético- de los jeroglíficos, es decir, la vinculación directa de tales signos con la divinidad y sus atributos. [...] Establece una neta diferencia entre 'semejanza' e ‘imagen”” (Pascual Buxó 137). Pero no puede obviarse que aunque una alegoría es en principio una mecanización simbólica, mantiene aletargada una función que la religa a principios metafísicos y espirituales (Cirlot 46). Kircher cree que los jeroglíficos son "símbolos que contienen divinas verdades ocultas" (Yates, Giordano Bruno 472) y mi teoría es que sor Juana activa al alegórico Neptuno creando desde intrincadas similitudes jeroglíficas una imagen de perfección superior que busca cumplirse e identificarse con el virrey verdadero o real, seduciéndolo y vinculándolo desde un ideal máximo cuando alude a él como "esperamos mejor Neptuno" al hacer sus peticiones. La alegoría sorjuanina, pues, supera la definición de mera mecanización simbólica, acercándose más a la idea calderoniana dramática de "concepto imaginado" en "representable idea” explicado por Martin (Concepto 27-44): la alegoría, a través del fantasma o imagen, representa y hace visible e inteligible una realidad conceptual de trascendencia y misterio divinos. ${ }^{13}$ Por tanto, siguiendo un esquema alegórico que juega con la cuestión platónica sobre la mímesis y la inferioridad artística, ante la excelsitud de la naturaleza y las obras presupuestas del virrey auténtico, éstas sólo pueden expresarse por aproximación a través de "ideas y jeroglíficos que simbólicamente representen algunas de las innumerables prerrogativas que resplandecen en vuestra excelencia” (68). Sor Juana coloca con gran inteligencia una comparación en la que el ideal, el término original de esa comparación quiere identificarse con el propio virrey y el modelo surgido, inferior, con el dios Neptuno. ${ }^{14}$ Es decir, Neptuno -el gran dios de la antigüedad-es irónicamente

\footnotetext{
${ }^{13}$ Hay que tener en cuenta en cualquier caso el sincretismo de la tradición alegórica que puede estar usando sor Juana: "La alegoría sorjuaniana no solamente abarca una multiplicidad de tradiciones medievales, renacentistas, barrocas y de la temprana modernidad sino que también traduce a nivel textual una diversidad de discursos y prácticas que forman parte del contexto sociocultural colonial y metropolitano. De esta manera, la alegoría poética es concebida como una forma de actuación social y pública” (Grossi, "De la fiesta” 666). Véase el capítulo 4 del libro de Grossi (Sigilosos 91-102) dedicado a este aspecto alegórico en el Neptuno.

${ }^{14}$ Es interesante notar que, mientras que el tema mitológico es habitual en estos arcos, "[l]as decoraciones de los arcos de triunfo erigidos con motivo de las entradas de virreyes buscaba la alabanza y exposición pública de la persona del virrey, relacionándola con una figura sacada de la mitología, que, salvo excepciones, no solía ser ninguno de los grandes dioses. En esto había una clara diferencia con las fiestas dedicadas a integrantes de la familia real, en las que sí eran frecuentes las comparaciones con deidades importantes" (Morales Folguera 289-90). El arco de sor Juana es una de estas excepciones, ya que normalmente se elegía a semidioses o héroes clásicos. Sor Juana anota esta decisión por no

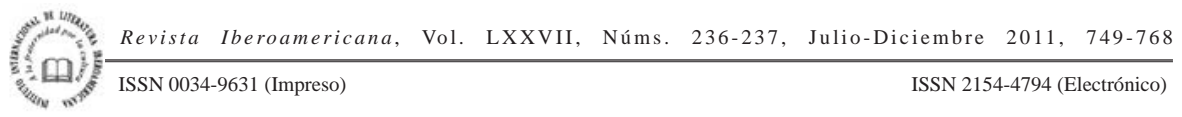


una copia imperfecta y alegórica del virrey, y por medio de esto sitúa al virrey al final de una genealogía de analogías simbólicas en las que él es epígono y culminación, figura ideal encarnada que ya se prefiguraba en el dios Neptuno. ${ }^{15}$ Este mecanismo va a permitir que en Neptuno, siendo sólo un modelo inferior, se dibuje un espejo donde el virrey auténtico y humano pueda mirarse, buscando sor Juana que se identifique con esa imagen ideal que le propone. Así, imagen ideal -que supuestamente es el propio virrey-, y el virrey espectador de esa imagen ante sí -que no puede tenerse por menos-, tienden a confundirse en la intencionalidad del subterfugio retórico. Lo cual activa la alegoría del dios Neptuno y la vincula, por esa imagen ideal de virrey, al virrey mismo. Por supuesto, éste cumple además el requisito genérico de complacer exageradamente al virrey como perfectísimo varón, y exponerle sin menoscabo un espejo de príncipes, expresando cómo le gustaría a sor Juana que fuera realmente su virrey. Ahora bien, instituyendo al virrey como original, digno además de ser asemejado sólo a un dios y no a cualquier otro héroe, lo coloca también en el mundo platónico de las ideas, esto es, dentro de la cosmovisión todavía ptolemaica relativa a este sistema, en el mundo supralunar, el de las estrellas fijas del macrocosmos, donde residen las ideas puras y cuyos influjos sufren los hombres. ${ }^{16}$ Sor Juana justifica esta elevación divina, inusual para un virrey a quien corresponde la categoría máxima de héroe, asegurando que los dioses eran príncipes muy perfectos que ascendieron a esta categoría. Desde luego, la similitud de esta comparación con el virrey auténtico que lee el Neptuno reside en que su excelsa jerarquía lo eleva automáticamente a las más altas esferas de decisión sabia sobre el destino mexicano. Y sor Juana, que como religiosa y mujer no participa

encontrar entre los héroes nadie que se le pueda comparar, detallando además, en consonancia con una línea apologética habitual para evitar la censura contrarreformista, que estos eran príncipes históricos excelentes que la tradición premió con el título de dioses (López Poza 251); y es que, como se verá, el acuático Neptuno le cuadra muy bien al Marqués de la Laguna y las pretensiones de sor Juana.

15 “[...] porque la Naturaleza, con las cosas muy grandes, se ha como un diestro artífice, que para sacar la obra a todas luces perfecta, forma primero diversos modelos y ejemplares en que enmendar y pulir lo que no fuere tan perfecto, porque después la obra tenga todas las circunstancias de consumada: y así ninguna cosa vemos muy insigne (aun en las sagradas letras) a quien no hayan precedido diversas figuras que como en dibujo la representen” (de la Cruz, Neptuno 75-76). Esta técnica se liga a la idea teológica de tipo y antitipo, por la cual un personaje del antiguo Testamento refleja un estadio imperfecto y promisorio de su antitipo en el Nuevo Testamento (Regalado 98-99): éste parece ser el proceso, en su versión mitológica, emulado aquí en la vía de perfección desde el imperfecto dios Neptuno pagano al virrey mesiánico de perfección cristiana.

16 Este modelo había quedado filosóficamente apuntalado en el Renacimiento por los textos sincréticos de Marsilio Ficino y León Hebreo en los siglos XV y xvi. En él, el mundo sublunar de las pasiones de los hombres se ve afectado por el movimiento puro e intelectual de los planetas o esferas superiores a la luna, en un ascenso jerárquico hasta alcanzar a Dios, tras el manto de estrellas fijas, que todo lo mueve. El hombre puede aspirar por el alma intelectiva a superar sus pasiones y elevarse hacia Dios mediante el conocimiento.

Revista Iberoamericana, Vol. LXXVII, Núms. 236-237, Julio-Diciembre 2011, $749-768$
ISSN 0034-9631 (Impreso) 
de esa jerarquía de poder, desde su posición de monja de clausura con aspiraciones a erudita intelectual de la corte, va a elevarse en el Neptuno -por el mero hecho de fabricarlo con sabia erudición e ingenio- hasta ese mundo de las ideas mediante el ejercicio intelectual de la fantasía; el objetivo es conquistar un papel de autoridad y por él colocarse a la misma altura cosmológica que el virrey -elevándose en la esferay así compartir sigilosamente un mismo campo de lid: todo ello ocurrirá gracias a la sutil manipulación de las imágenes simbólicas conceptuales con las que va a elaborar toda una red de correspondencias o vínculos. Esta red funciona para que, por un lado, el virrey se vea en el espejo realmente como culmen de una genealogía inevitable que nace en el dios Neptuno y termina necesariamente en él, y por otro lado, para que sor Juana pueda autorizarse a hablarle cara a cara, al menos de igual a igual y quién sabe, no ya obtener el favor del virrey, sino tomárselo por derecho propio y aspirar a ejercer, desde la misma elevada esfera de decisión que el virrey, un poder sobre la realidad.

La labor erudita completa de conexión entre la desbordante red de autoridades y significados simbólicos de Neptuno la expone muy bien López Poza en un extenso artículo sobre el Neptuno, y la manipulación de algunas de las conexiones clave elaboradas para que sor Juana se autorice como mujer sabia y poseedora de un poderoso conocimiento que la coloca por encima del virrey lo detalla a la perfección Vincent Martin en otro texto ("El Neptuno"). Aquí sólo voy a rescatar algunos ejemplos muy claros que nos permitan avanzar en la reflexión. Debemos recordar antes que Cirlot, en su Diccionario, señala que el simbolismo es el "arte de pensar en imágenes” (34), y que su esencia es la correspondencia entre sí de todos los órdenes de la realidad, permitiendo a esta correspondencia la circulación entre diferentes niveles (35). Veremos que ésta es la operación que realiza sor Juana, aplicando vínculos y concordancias en su fantasía de imágenes conceptuadas. En su aspecto visual y conceptual, los ocho lienzos simbólico-emblemáticos del arco condensan la alquimia de toda una densidad aquilatada de pensamiento encadenado por las imágenes simbólicas. Este arte de pensar en imágenes se identifica en la época con el arte de la memoria, proceso heredado de la tradición ciceroniana, tamizado por el arte lulliano medieval y adoptado por la filosofía esotérica renacentista: consiste en el ejercicio a través del cual se organiza un discurso retórico, aprovechando la creación de imágenes mentales que por analogía permitan recordar, engarzar y recorrer la lógica del discurso a la hora de enunciarlo. ${ }^{17}$ El Barroco, en una apropiación que culmina en la propaganda contrarreformista, va a exteriorizar

${ }_{17}$ Para un buen resumen con su relación emblemática en el Neptuno, ver Pascual Buxó (186-213). Para un desarrollo completo del tema, véase el libro de Yates, El arte de la memoria. En el campo hispánico, Rodríguez de la Flor ha desarrollado un continuo trabajo en torno a las implicaciones de este arte mnemotécnico desde su clásico estudio titulado Teatro de la memoria: siete ensayos sobre mnemotecnia española de los siglos XVII y XVIII.

ISSN 0034-9631 (Impreso) 
este modelo a través de toda la imaginería programática de retablos, arcos, emblemas. La creación de estas imágenes mentales se funda en el uso natural de la fantasía, ${ }^{18}$ que en ese momento se entiende como una herramienta de la percepción humana y funciona como catalizador de las percepciones obtenidas por los sentidos, a las que convierte en imágenes sensibles: el entendimiento aprehende mediante estas imágenes la realidad y la conceptualiza finalmente al transformarlas en imágenes intelectuales o ideas. Así, imagen e idea, artificialmente dispuestas y conectadas, se enlazaben para entender el mundo, pero también para modelarlo. En nuestro caso, el arco representa ante la sociedad la apoteosis figurada externalizada del poder virreinal, y el Neptuno, como arquitectura retórica, representa en su conjunto una técnica fantástica para hacer recordar al virrey el arco triunfal en el día de su entrada por él, y mediante asociaciones de imágenes atadas a conceptos -en un recorrido mnemónico por esta genealogía fantástica- recordarle las virtudes ideales del virrey y, como consecuencia de ellas, la necesaria actuación concreta en un determinado programa político.

La elección del dios marino va a permitir a nuestra artista de imágenes y analogías conectar ampliamente la naturaleza y destino de México, como urbe transatlántica edificada sobre una laguna, con el virrey que, cual Neptuno, viene a ultramar a gobernar lo que puede considerarse una isla a la deriva política: el título más notable del Marqués, el de la Laguna, permite afianzar o cerrar firmemente un círculo vinculador entre todos estos elementos:

Cupo a Neptuno en suerte el mar (como ya queda dicho), con todas las islas y estrechos. ¿Qué otra cosa fue esto, que ser Su Excelencia Marqués de la Laguna, general del Mar Océano, con todos los ejércitos y costas de Andalucía? [...] Y no sé qué mayor pueda ser la conexión; pues hasta en los clarísimos apellidos de Su Excelencia de hallan significaciones marítimas, cuales son: Porto Carrero y Ribera [...]. (de la Cruz, Neptuno 103-8)

Esto más tarde le permite, al describir el segundo lienzo del arco con Neptuno defendiendo de las aguas la ciudad de Inaco, explicar la representación, no ya con la virtud de piedad neptuniana, sino con la situación extrema del canal mexicano y una urgente petición:

Representaba esta inundación la que es continua amenaza de esta imperial ciudad, preservada de tan fatal desdicha por el cuidado y vigilancia de los señores virreyes, y nunca más asegurada que cuando no sólo tiene propicio juez, pero espera tutelar numen

${ }^{18}$ Para una breve historia del concepto de fantasía y su evolución, véase Serés. También Martin en cuanto al concepto barroco de fantasía como medio de percepción y conocimiento de la realidad (Concepto 31-32); Bruno la toma como puerta clave para vincular almas (Culianu 141-42).

ISSN 0034-9631 (Impreso) 
en el Excelentísimo Marqués de la Laguna: que si allá (como refiere Natal, tomándolo de Herodoto) formó Neptuno una laguna en que fluyesen las copiosas aguas del Peneo [...] nosotros esperamos mejor Neptuno, que contraponiendo la hazaña, forme un río por donde fluya una laguna, en su tan necesario como ingenioso desagüe. (126)

Si Neptuno es un modelo y el virrey un perfecto original, parece que aún le quedan hazañas para demostrar su perfección, y es la situación en la que ubica sor Juana al virrey lector del Neptuno, infiriendo una correspondencia que busca obligar a este virrey a ejercer su poder hacia un fin determinado en la práctica real de su gobierno. Ahora, la similitud es imperfecta a la inversa porque al virrey aún le quedan hazañas para parecerse o superar a su imperfecto modelo, aunque sin duda tenga las virtudes para ello. Encadenado a toda una genealogía bien establecida que lo liga al dios marino y sus virtudes, aquí el virrey diseñado por la erudición imaginativa y conceptual de la monja jerónima se ve en la necesidad de admitir que no puede hacer otra cosa. Así, aprovechando estos vínculos elaborados, en el tercer lienzo se descubre a Neptuno anclando en la viajera isla de Delos, y esto sirve para ligarlo de nuevo con otra piadosa hazaña del dios de las aguas, y una segunda petición explícita:

Representaba todo este vistoso aparato a nuestra imperial México; y no sé quémás propia copia suya pudiéramos hallar, pues demás de convenirle por su fundamento el nombre de isla, según su definición [...] qué más manifestum, et apparens, que la que tantos siglos se ocultó, como en el mar, pues el temor de éste estorbaba su descubrimiento? Y así, parece que se apareció al mundo a merced de Neptuno; pues éste dio paso por sus ondas para poder gozar sus inmensas riquezas, [...] y la mayor grandeza suya gozar los favores de mejor Neptuno en nuestro Excelentísimo Príncipe, con quien espera gozar estables felicidades, sin que turben su sosiego inquietas ondas de alteraciones ni borrascosos vientos de calamidades. (130-31)

La isla debe ser gobernada por este Neptuno que ha cruzado las aguas desde España, a modo de evitar mareas sociales. Y la última petición corresponde al último y octavo lienzo:

En el octavo y último lienzo (que fue el que coronó toda la montea), se pintó el magnífico Templo Mejicano de hermosa arquitectura, aunque sin su última perfección: que parece le ha retardado la Providencia, para que la reciba de su patrón y tutelar Neptuno, nuestro excelentísimo héroe. (163)

Se invita a terminar las obras de esa catedral que está tras el arco, y bajo el cual el virrey ha entrado en ella. Anteriormente sor Juana había recordado a Neptuno como arquitecto de los muros de Troya, lo cual hace esta petición igualmente lógica y grandiosa. Crea así una red perfecta en la que la manipulación de imágenes ordenadas por el ingenio de la fantasía es la clave de su vinculación hacia un objetivo también práctico.

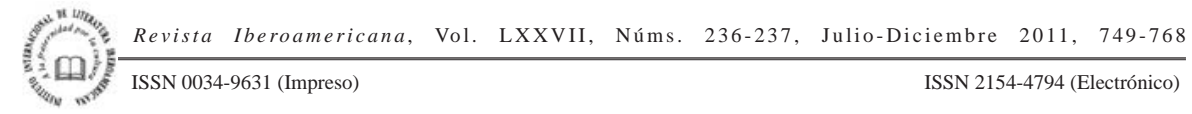


De forma intensa vemos en todo esto un continuo y laberíntico juego de concatenaciones que nos recuerdan al afán sorjuanino por kircherizarlo todo, ${ }^{19}$ como en el arte combinatoria de este sabio humanista que buscaba mediante tal arte la unidad del conocimiento universal. Sor Juana parece aludir a la filosofía de Kircher en su Respuesta como elemento necesario del ejercicio especulativo, donde todos los saberes ayudan al conocimiento último, puesto "que no sólo no estorban, pero se ayudan dando luz y abriendo camino las unas para las otras, por variaciones y ocultos engarces -que para esta cadena universal les puso la sabiduría de su Autor-, de manera que parecen que se corresponden y estén unidas con admirable trabazón y concierto" (Obras IV 450). ${ }^{20}$ Le sigue una afirmación de resonancias a la vez ficinianas y de geometría matemática, al asegurar además que "todas las cosas salen de Dios, que es el centro a un tiempo y la circunferencia de donde salen y donde paran todas las líneas criadas” (450). La teoría del vínculo bruniana aparece así reflejada, no ya en la relación específica entre los individuos y sus roles, sino en la de las ciencias y saberes que constituye el entramado interior de engarces magnéticos -pues todo lo atraen en torno al virrey- del Neptuno; e implica definitivamente esa visión concatenada por la que, según los neoplatónicos, podía llegarse hasta Dios mismo, Scala Dei, concepto a concepto, escala que de diversos modos sor Juana intentará infructuosamente aprehender en el Primero sueño. Esta red vinculada es la que permite ascender a sor Juana hasta el virrey mismo, y con la que pretende ligarlo en un acto de seducción o atracción magnética mediante una potente y tramada imagen ideal.

Concepto por concepto, entonces, eslabonadamente, los vínculos crean una lógica atractora e ineludible desde la analogía simbólica en su recorrido por la lectura de las

19 "Pues si la combinatoria, en que a veces kirkerizo, en el cálculo no engaña y no yerra en el guarismo, [...]" (de la Cruz, Obras I 158). La propia sor Juana crea el neologismo en los versos de este romance de imágenes mágico-herméticas en el que ironiza sobre su vocación poética y desvela ingeniosamente el nombre del oculto caballero a quien responde: el conde de la Granja, quien ha elogiado a la monja en un poema anterior nombrándola musa mejicana.

20 "Es la cadena que fingieron los antiguos que salía de la boca de Júpiter, de donde pendían todas las cosas eslabonadas unas con otras. Así lo demuestra el R. P. Atanasio Quirquerio en su curioso libro De Magnete" (de la Cruz, Obras IV 450). Findlen (357) recupera esta relación con el libro de Kircher, que se titula en realidad Magneticum naturae regnum, de 1667, y que estaba dedicado a un criollo llamado Fabián, contemporáneo de sor Juana, y que mantenía una correspondencia intensa con Kircher (para leer estas cartas, véase el epistolario de Osorio). Para ver la cadena magnética en el contexto sincrético de la cultura de Kircher, y su obra y aplicaciones prácticas, véase Vermeir, con referencias expresas a este pasaje que se relaciona directamente con su teoría de la luz (377-79, 381). En el libro de Godwin, que repasa con ayuda de numerosas imágenes la obra de Kircher, puede verse la imagen que inspiró a sor Juana (75). El lema o motto que lo acompaña dice que "el mundo está ligado por nudos secretos" y la imagen representa la cadena de simpatías que enlaza en todos los niveles a los seres del universo. Ésta es la cadena del ser por la que viaja un mago hermético para alterar el estado de cosas, ascendiendo a los poderes planetarios o angélicos con capacidad de obrar.

Revista Iberoamericana, Vol. LXXVII, Núms. 236-237, Julio-Diciembre 2011, $749-768$
ISSN 0034-9631 (Impreso) 
imágenes, gracias a ese juego de correspondencias construido cuidadosamente por sor Juana en torno al dios y al virrey. Un conjunto de asociaciones que no se basan exclusivamente en la autoridad de los textos anteriores, como señala Grossi, por ejemplo, para "[l]a asociación analógica que establece sor Juana entre Neptuno y Harpócrates, dios del silencio. Esta asociación no aparece en las fuentes de la antigüedad que cita sor Juana para autorizar su composición e interpretación alegórica” (Sigilosos 100).

Si bien Neptuno y Harpócrates están ligados por una tradición que Sigüenza y Góngora remonta a Plutarco, Ausonio y Varrón, en la que el dios Conso de los consejos se identifica con ambos, ${ }^{21}$ la relación entre Harpócrates como dios del silencio y Neptuno como dios silencioso no queda más que sugerida por una lógica implícita en dicha asociación del trío, de forma que sor Juana se pregunta por "la razón de haber los antiguos venerado a Neptuno por dios del silencio, confieso no haberla visto en autor alguno de los pocos que yo he manejado” (84). Una fuente sorjuanina, Vitoria, siguiendo a Cartario, establece la relación entre el silencio de Harpócrates con la mudez del pez, ${ }^{22}$ y parece ser que con tal apoyo sor Juana propone ya explícitamente que "por ser dios de las aguas, cuyos hijos los peces son mudos” (84), Neptuno se convierte en dios del silencio. ${ }^{23}$

\begin{abstract}
Aquí sor Juana revela abiertamente que la analogía mimética que representa el tejido alegórico del Neptuno alegórico no es producto de la necesidad, de la imitación de un modelo real, existente, trascendente, sino del ingenio inventivo de la autora por medio del cual manipula, modifica y hasta distorsiona una multiplicidad de fuentes mitográficas. Sor Juana muestra un poder y un dominio totales sobre el juego de alegorizaciones desplegadas en el texto. (Grossi, Sigilosos 100)
\end{abstract}

Este afán por la perfección e intensidad en la alegoría sólo muestra que es capaz, y se siente con autoridad, para alterar o proponer el orden de las cosas y, con ello, lograr un artefacto simbólico personal de gran efectividad adecuado a sus designios. ${ }^{24}$ Sus vínculos buscan crear una alianza redonda, y con el vínculo ejemplificado sor Juana ha dado un paso más allá en el juego simbólico, cerrando un Neptuno si cabe más propio, pues lo dota definitivamente de silencio, además de la meditación, el consejo, la sabiduría y piedad que ya había añadido a lo largo del texto al tradicionalmente primario y masculino

${ }^{21}$ Véase para las citas clásicas la edición de Martin (82, nota 53; 106, nota 125).

22 Véase para las citas clásicas la edición de Martin (86, nota 62).

${ }^{23}$ Véase la discusión de esta cuestión en Paz (218), quien propone el objetivo sorjuanino de crear un Neptuno silente y hermético frente al más tempetuoso de la tradición.

${ }^{24}$ En el artículo de Martin (170-74) puede apreciarse la compleja y sutil manipulación que hace de la relación Io-Isis para hacer de la sabiduría una condición doblemente femenina y así otorgarse el papel de diosa sabia a través de Isis y Minerva, como veremos.

ISSN 0034-9631 (Impreso) 
poderoso rey de los mares. ${ }^{25}$ Sor Juana ya tiene su Neptuno, elaborado con su arte de la memoria kircheriano e íntimamente ligado tanto a México como al nombre y títulos del Marqués, cual si éste fuera cifra cabalística del virreinato.

Bruno denomina mago al manipulador de imágenes de la fantasía. Y ese mago altera la realidad porque es capaz de conectar secretamente estas imágenes o fantasmas, y por sus simpatías transformar la realidad. Se ha visto el Neptuno como un fantasma que sustituye y supera al arco ausente y su ceremonia (Grossi, Sigilosos 101); pero es ya algo más. Como ejercicio de fantasía por medio de imágenes conceptuales que construyen el Neptuno, éste queda conectado, si seguimos a Bruno, a la magia ejercida por el mago como manipulador de fantasmas, operación que consiste en ordenar y disponer a su voluntad dichos fantasmas, sin caer por supuesto en ellos (Culianu 135). Sor Juana estimula todo un ejercicio de arte de la memoria retórica a través de la analogía simbólica en la búsqueda de la creación de conceptos elevados. Elabora para ello una fantasía de imágenes conceptuales vinculadas entre sí, de la que resulta un Neptuno sincrético civilizador frente al clásico tempestuoso. ${ }^{26}$ Este dédalo imaginístico produce un simulacro político ${ }^{27}$ que se expone ante el virrey como imagen de sí mismo y su programa, no tanto pidiéndole como convenciéndole, atrayéndole, seduciéndole, atándole por fascinación magnética, a través de este aparato analógico, a la necesidad de no defraudar a sus súbditos en tres proyectos concretos. Se le plantea el Neptuno al virrey entonces como proyección mental de sí mismo, como una fantasía visual poderosamente elaborada con el propósito de vinculación a dicha fantasía, a la imagen esplendorosa y fascinante que sí es el propio texto. La sustitución de la tabula rasa que es el alma del recién estrenado virrey por una imagen ideal elaborada y manipulada por

25 "Parte del programa político barroco de sor Juana es un intento lingüístico conceptual de abrir tiempos y espacios a las virtudes y valores excluidos” (Arenal, "Enigmas” 92).

26 "Genealogía sincretista: el arquetipo del Marqués de la Laguna no era realmente el grecorromano Neptuno sino una divinidad compuesta, en la que se acoplaban distintos atributos y deidades, entre ellas y principalmente un dios niño egipcio (Horus) en su forma helenizada: Harpócrates. El proceso de transformación de sor Juana tendía a intelectualizar e interiorizar a Neptuno para convertirlo, de dios tempestuoso y progenitor de monstruos espantables como Polifemo y el gigante Anteo, en una deidad civilizadora cuyos atributos eran la sapiencia, la cultura y el arte” (Paz 219).

27 Martin destaca en su edición al Neptuno (ver nota 1) que el significado de simulacro aquí se engloba en el sentido condensado en el Diccionario de Autoridades: "Imagen hecha a semejanza de alguna cosa venerable, o venerada” (63). El Neptuno alegórico es simulacro político por buscar la similitud entre el dios Neptuno y las gracias morales del virrey. Sin embargo, la definición de San Isidoro, que también cita Martin, implica no sólo semejanza o similitud, sino también la acepción de simulado o imaginado, con el carácter necesario de falso (64). Dado que todo el texto es un trabajo de la fantasía tramado en un entorno Barroco, todo el artefacto retórico y visual puede reconocerse también como un juego de apariencias, por lo tanto falso o equívoco a los sentidos, como la propia manipulación intelectual que está ejerciendo sor Juana.

Revista Iberoamericana, Vol. LXXVII, Núms. 236-237, Julio-Diciembre 2011, $749-768$
ISSN 0034-9631 (Impreso) 
sor Juana, pero fabricada desde la analogía más estrecha entre el nombre y títulos del Marqués, se convierte en la misión del Neptuno como espejo de príncipes que reclama acción concreta en un virrey proyectado como poderoso, piadoso y sabio. En realidad, el Neptuno se aprecia así como un conjuro verbo-visual de signos y figuras de máxima potencia elaborado por sor Juana, a modo de talismán. ${ }^{28}$ Los talismanes eran objetos simpáticos a un planeta o dios e inscritos con un signo o figura capaz de conectar con esa divinidad planetaria capaz de proteger o actuar para quien lo portaba. ${ }^{29}$ El Neptuno, como talismán, pretende obligar al auténtico virrey -mediante su original invocado por la fantasía como un perfecto dios, según el espejo sorjuanino- a actuar de una determinada manera y cambiar el orden de las cosas en el mundo de los mortales. No en vano, el virrey había cruzado el arco -símbolo de pacto divino con los hombres-, la puerta a su alianza como regidor de Nueva España, y al hacerlo había pasado bajo la mágica arquitectura de alquimia visual y jeroglífica de sor Juana y su simulacro político. Y, aún después por el Neptuno, bajo el influjo de las imágenes recuperadas por aquel arco perfectamente trabado de carácter cósmico e interpretadas luego por los conceptos visuales de la lectura. ${ }^{30}$ Sor Juana parece estar pensando en ejercer sobre el virrey un efecto persuasivo que, visto desde el papel de la fantasía, la fascinación y el arte de la memoria, para un neoplatónico tiene calidad de mágico por la belleza y perfección armónica de las formas, colores y conceptos; para un bruniano esta obra ejemplifica

${ }^{28}$ Sor Juana podría estar desarrollando entonces algunos aspectos de la magia matemática o filosofía oculta en dirección a la búsqueda de intermediación por invocación de espíritus divinos superiores de conocimiento, superando los límites ortodoxos de la pura magia natural: “[...] si se recurre a la virtud de simpatía y antipatía de las cosas, como cuando unas sustancias rechazan, transmutan o atraen otras sustancias (así como el imán y cuerpos parecidos cuyas operaciones no se reducen a las cualidades activas y pasivas sino que atañen todos al espíritu o al alma que existe en las cosas), se habla con toda razón de magia natural. Si se añade a esto, en quinto lugar, palabras, fórmulas, relaciones numéricas y temporales, imágenes, figuras, sellos, caracteres o letras, se trata de una magia intermediaria entre la magia natural y la magia extra-natural o sobrenatural, que hay que llamar propiamente magia matemática, o mejor aún filosofía oculta" (Bruno 14).

29 Sor Juana imagina, fantasea eruditamente, y vincula mediante imágenes hasta crear todo un universo especular de perfección virreinal. Podríamos decir que, como otras muchas asociadas al arte de la memoria de su tiempo, las suyas “[...] contienen dentro de sí el secreto mismo de la organización ideal del cosmos. Es decir, alcanzan lo que podríamos denominar un carácter talismánico (pero desde la tradición cristiana se diría sagrado, iconolátrico), en el sentido de que en ellas el contacto con la cosa verdadera está muy próximo; casi puede decirse que, en cierta manera, imagen y cosa son o pueden llegar a ser lo mismo. Poseer intelectualmente la imagen es bañarse, sumergirse en la cosa que representa y fija” (Rodríguez de la Flor, Emblemas 188).

${ }^{30}$ Los versos finales de la loa invitan al virrey a pasar bajo el arco, ambos de macrocósmicas dimensiones: "Entrad, Señor, si el que tan grande ha hecho / tantos años la sabia arquitectura, / es capaz de que quepa en su estructura / la magnanimidad de vuestro pecho. // Que no es mucho si allá le vino estrecho / el templo, de Neptuno a la estatura, / que a vos la celestial bóveda pura / os sirva sólo de estrellado techo” (de la Cruz, Neptuno 201).

Revista Iberoamericana, Vol. LXXVII, Núms. 236-237, Julio-Diciembre 2011, 749-768 ISSN 0034-9631 (Impreso) 
un claro efecto manipulador: el virrey es interpretado como instrumento ejecutor de la sabiduría expuesta por sor Juana. ${ }^{31}$

De hecho, el cuadro no quedaría completo en este portentoso simulacro político si sor Juana no apareciese proyectada en el lienzo séptimo, dedicado a la competencia entre Neptuno y Minerva, con Minerva como vencedora (a más gloria de Neptuno), ya que "fue hazaña y no cobardía el ser vencido: pues no era otra cosa Minerva, que su propio entendimiento, a quien sujetaba todas sus acciones para conseguir doblada victoria” (160). Y, en relación con la diosa, no se olvide que al plantear la genealogía de Neptuno como sabio sor Juana recurre a la diosa egipcia Isis, a quien documenta mediante autoridades entre las mujeres sabias e inventora de las letras egipcias (87). No hay duda de que sor Juana es asimismo la inventora de los jeroglíficos del Neptuno, y por tanto digno reflejo de Isis (¿o quizás su original, perfeccionado con el tiempo?). Y con su entendimiento -claramente demostrado por la aplicación de ingenio tan subido-, es también reflejo perfecto de Minerva. ${ }^{32}$ La sabiduría de Neptuno comienza en Isis y se completa en Minerva. Se concibe así una alianza política de vínculos fantásticos cuya transposición en la realidad no es sino la legítima aspiración de asesorar al virrey, y reclamar un puesto de mujer sabia que “quiere ganar voluntades” (Sabat de Rivers 70). ${ }^{33}$

31 De modo general, recordemos que "la magia se basa en el conocimiento de las relaciones mutuas existentes entre todas las cosas integrantes de la naturaleza; en la comprensión de las secretas simpatías por las que una cosa puede ser atraída por otra. De modo que el mago, en cualquier tradición mágica, es aquél que fuerza a las cosas inferiores con los poderes de las cosas superiores” (Alonso Palomar 41). A pesar de la problemática de los jeroglíficos sorjuaninos planteados inicialmente como meras similitudes no confundibles con el objeto comparado, a estas alturas adquieren un potencial mayor al pretender dirigir la actividad política del virrey, con toda esa virtuosa máquina manipulada por sor Juana de materiales herméticos incluidos en sus analogías. En el hermetismo, la magia da mucha importancia a los talismanes (Alonso Palomar 41), a los que Ficino y Pico della Mirandola les dedicaron atención. Al menos de una manera analógica, por similitud imperfecta, podríamos nosotros decir ya que es así como la monja pretende, tras el ejercicio retórico de vinculación, ejercer cambios en el virreinato de México por acto de magia.

32 "She celebrated Isis as the Great Mother (Magna Mater) of whom many ancients and Renaissance authors had written, siding with thouse authorities who argued she was the template of Minerva. [...] Isis became the mirror of her own erudition” (Findlen 350-51). Egan dedica un estudio a la divinidad femenina en la obra de sor Juana, con referencia explícita a la relación entre Isis y Minerva, a la que se añade el resto del jeroglífico con Venus y María (332-33). Sobre Isis y su uso en el Neptuno en relación a sus fuentes, ver Paz (229-36).

33 El reclamo de este lugar nunca otorgado parece hilar toda su obra hasta culminar en la Respuesta, y su condición de maga -que persigue el saber unido al poder de obrar a placer-podría explicar gran parte de su actitud ideológica, tan valiente como perseguida, al tiempo que acentuar en ella el gusto por alterar y manipular la tradición imperante en su búsqueda del conocimiento. Recordemos que en el Sueño alcanza por ascensus la visión divina de todas las cosas, aunque su entendimiento deba retirarse apabullado. Por otro lado, si Bruno murió en la hoguera tachado de hereje, sor Juana lo hizo en la invisible del silencio. Véase el artículo de Trabulse (143-55) sobre este silencio final, desencadenado en parte por una alabanza

\footnotetext{
Revista Iberoamericana, Vol. LXXVII, Núms. 236-237, Julio-Diciembre 2011, $749-768$
ISSN 0034-9631 (Impreso)
} 
Como trasfondo del tapiz de su simulacro flota toda una conexión de genealogía hermética donde México y su virrey -como en la imagen sincrética del templo azteca kircheriano ${ }^{34}$ - son iluminados por la luz de Egipto (Findlen 350-51): en él, sor Juana se propone a sí misma como diosa sabia y pretende, en su Neptuno, autorizarse para influir desde esta elevación celeste al virrey, al que ha modelado fantásticamente como un poderoso regido por la sabiduría. En su contraparte, el virrey es en la realidad el máximo poder civil y militar en México. De este modo, establece en sí sor Juana la compostura de un mago al estilo bruniano, que por la manipulación de atractoras imágenes simbólicas dirigida sobre el espíritu de un individuo, busca el propósito de modificar a su placer el universo virreinal. Si bien en la fantasía Minerva es la faz femenina de Neptuno -y por ello representa el entendimiento que caracteriza al virrey en el texto del Neptuno-, en la realidad es sor Juana la que busca ejercer esa faz, como mujer sabia que aspira a poder obrar mediante el cuerpo masculino del virrey y toda la institución patriarcal de la ciudad letrada. Por lo tanto, sor Juana aspira al papel de maga en el sentido que Bruno le da inicialmente al término: "tal como se la emplea entre los filósofos, esa palabra mago designa un hombre que alía el saber al poder de obrar” (16); y también recuerda Bruno que antiguamente "mago ha significado en primer lugar sabio" (13). Sor Juana es maga por sabia, primeramente, ya que es capaz de plantear con sutileza y complejidad todo un aparato fantástico magnéticamente encadenado en el que incluye con naturalidad indiscutible e irrechazable ciertas peticiones a un virrey. Y sor Juana es aspirante a maga porque con su saber desea obtener el poder de obrar, proyectando este saber por medio de la fantasía erudita sobre el virrey, que es quien deberá obrar influido y vinculado por el seductor espejo magnético del entendimiento sorjuanino. ${ }^{35}$

Parece evidente que si el concepto con el que se elaboraban los arcos se basa en la agudeza de ingenio popularizada por Gracián (Pascual Buxó 139), esta agudeza tenía varias dimensiones además del de notoriedad vanidosa, o puro ingenio en el caso de sor Juana, pues buscaba una efectividad práctica gracias a la arquitectura imaginística y verbal que había desarrollado. En los versos introductorios a su loa o explicación

de Palavicino a la Carta Atenagórica, acto que produjo un proceso inquisitorial contra él, planificado en torno a la monja y su actividad intelectual.

34 Imagen que utiliza Kircher en su Oedipus Aegyptiacus (1652-1655) en su afán sincretizador de unir Viejo y Nuevo Mundo. Algunos comentarios sobre la imagen de Kircher se encuentran en Findlen 350-51 y Godwin 60.

35 Vincent Martin destaca cómo el juego de concatenaciones es tan sutil y erudito -a modo de genial prestidigitación alegórica- que impide al virrey ver el juego con el que sor Juana se coloca como sabia, y en última instancia, elabora una alabanza que se desvía de la figura oficial monárquica a la del arco triunfal imaginado en honor al conocimiento que es el texto sorjuanino ("Neptuno" 174). Sin duda, esta invisibilidad que adquiere la autora escondiéndose tras la prestidigitación alegórica explicada por Martin es la clave no sólo de la autoridad secreta que se logra otorgar por el control ejercido sobre los fantasmas alegóricos, sino también del poder que secretamente pretende ejercer con ellos.

Revista Iberoamericana, Vol. LXXVII, Núms. 236-237, Julio-Diciembre 2011, 749-768 ISSN 0034-9631 (Impreso) 
del arco, lo presenta como "Este, Señor, triunfal arco, / que artificioso compuso / más el estudio de amor / que no el amor del estudio" (de la Cruz, Neptuno 189). Para sor Juana parece importar más que el puro ingenio erudito, la fuerza que para los platónicos representa el eros o amor, elemento quintaesencial que une y vincula los elementos del universo, fuerza por la que transmite la divinidad sus cualidades de atracción/repulsión a los seres de la cadena universal. Sor Juana parece centrarse en el estudio de esos eslabones que engarzan los elementos del cosmos, como vimos en un ejemplo anterior extraído de la Respuesta. Para Bruno, en su teoría vinculatoria, el eros forma parte de la fuerza que debe manipular el mago o fascinador a través del deseo o los afectos asociados al individuo (113); estos afectos son los que intenta sor Juana despertar en el virrey, quizás desde la vanidad o el heroismo por la fama, hacia esa imagen de fuerza y perfección suma que el político debería amar, sentirse atraído y finalmente ligado. Es interesante señalar además que la esposa del virrey, enlazada también al mar por su nombre -doña María-, figura como Anfitrite, personaje que Bruno califica como fuente de los vínculos eróticos (108). En el Neptuno aparece relacionada con la estrella del mar, y por tanto Venus, la belleza y su imperio (181-88). El neoplatonismo se justifica como una consecución del amor por el deseo de la posesión de la belleza. Así, el amor del estudio, o del conocimiento, se vuelve clave en la construcción del arco y su belleza lograda por ejercicio del amor. En el soneto de despedida de la loa, con la invitación a entrar en la catedral, se convierte en un amor edificante de un arco que da paso al templo espiritual de dimensión macrocósmica, por el cual entran los endiosados virreyes: "pero entrad, que si acaso a tanta alteza / es chico el templo, amor os edifica / otro en las almas de mayor firmeza / que de mentales pórfidos fabrica: / que como es tan formal vuestra grandeza, inmateriales templos os dedica" (de la Cruz, Neptuno 202). Mediante su Neptuno, sor Juana busca dar paso a este otro templo en sus almas, tras influir sobre ellas mediante el recorrido de imágenes simbólicas encadenadas donde queda patente ahora toda una técnica secreta del eros magnético que se aplica sabiamente a través de la puerta de la fantasía y que se expande vigorosamente en la mente. En definitiva, la intermediación mágica de sor Juana ante el virrey -que es presentado al fin como dios y por tanto capaz de cambiar el estado de las cosas bajo su influjo- se da a través de toda una técnica fantástica, máquina de una mágica arquitectura, que busca transformar con la ayuda de ese fantasma conceptual el universo novohispano en el que vive. Si en la fantasía Neptuno se rinde ante Minerva, y su poder es ejercido sólo desde la sabiduría de la diosa, del virrey, como "mejor" Neptuno, se espera que se rinda ante el espejo mágico que sor Juana, mujer sabia, le tiende como una ramita de olivo. ${ }^{36}$

${ }^{36}$ Finalmente, el canal no se terminó bajo este virrey, y siguió estancado como venía por desavenencias entre el ingeniero y los letrados que no quedaron resueltas hasta la llegada del siguiente virrey a partir de 1686 (Rodríguez-Sala 288-92). Tampoco la catedral fue terminada hasta el siglo xix, como señala Salceda

\footnotetext{
ISSN 0034-9631 (Impreso) 
Arenal, Electa. "Enigmas emblemáticos: El Neptuno alegórico de sor Juana Inés de la Cruz”. Sor Juana y su mundo: Una mirada actual. Memorias del congreso internacional. Carmen Beatriz López-Portillo, coord. México: Fondo de Cultura Económica, 1998. 85-94.

Introducción. Sor Juana Inés de la Cruz. Neptuno alegórico. Vincent Martin, ed. Madrid: Cátedra, 2009. 9-45.

Alonso Palomar, Pilar. De un universo encantado a un universo reencantado. Magia y literatura en los siglos de oro. Valladolid: Grammalea, 1994.

Boyer, Agustín. "Programa iconográfico en el Neptuno alegórico de sor Juana Inés de la Cruz”. Homenaje a José Durand. Luis Cortest, ed. Madrid: Verbum, 1994. 37-46.

Bruno, Giordano. De la magia. De los vínculos en general. Buenos Aires: Cactus, 2007.

Catalá, Rafael. “Sobre el Neptuno alegórico de Sor Juana”. Café-Lit6/31-32(1983): 29-33.

Checa, Fernando. “Arquitectura efímera e imagen del poder”. Sor Juana y su mundo. Una mirada actual. Sara Poot Herrera, ed. México: Universidad del Claustro de Sor Juana, 2005. 253-305.

Cirlot, Juan Eduardo. Diccionario de símbolos. Barcelona: Labor, 1978.

Cruz, Sor Juana Inés de la. Obras completas I. Lírica personal. Alfonso Méndez Plancarte, ed. México: Fondo de Cultura Económica, 1951.

Obras completas IV. Comedias, sainetes y prosa. Alberto G. Salceda, ed. México: Fondo de Cultura Económica, 1957. Neptuno alegórico. Vincent Martin, ed. Madrid: Cátedra, 2009.

Culianu, Ioan Pietro. Eros y magia en el Renacimiento. Madrid: Siruela, 1999.

Egan, Linda. “Donde Dios todavía es mujer: sor Juana y la teología feminista”. Y diversa de mí misma entre vuestras plumas ando. Homenaje internacional a sor Juana Inés de la Cruz. Sara Poot Herrera, ed. México: El Colegio de México, 1993. 327-40.

en las notas al Neptuno (de la Cruz, Obras IV 620). Pésimo y mediocre político (Paz 204), don Tomás de la Cerda sufrió fuertes insurrecciones (Paz 245-46; Orozco 107-8) y parece que sólo se preocupó por su fortuna personal, fue multado y expulsado por ello (Flores Rangel 65). En descargo de sor Juana podemos decir que para vincular completamente con el virrey es necesaria cierta fe previa en el operador mismo (Bruno 48); dada la personalidad real del virrey, muy inferior finalmente del dibujo esbozado, no parece que tuviera un ápice de interés en dejarse seducir por el Neptuno ni cualquier otro ideario político, así que a la monja le falló la mayor, y su dios sabio no parecía tener la altura suficiente a la que sor Juana se dirigía como capaz de intervenir en el destino de México. Al menos nuestra monja, otorgando otra función más duradera a su obra gracias al amor artístico e intelectual, se elevó lo suficiente sobre el arco y el virrey efímeros como para dejar digna memoria de sí y de su templo espiritual. Como señala Grossi: "La memoria escrita, producto de la imaginación poética, sustituye el evento y monumento histórico centrado en la autoridad del monarca" y reclama "el valor superior del ingenio artístico femenino que sitúa a la creadora por encima de toda jerarquía institucional e incluso por encima del poder divino" (Sigilosos 101-2).

Revista Iberoamericana, Vol. LXXVII, Núms. 236-237, Julio-Diciembre 2011, 749-768 ISSN 0034-9631 (Impreso) 
Findlen, Paula. "A Jesuit's Books in the New World. Athanasius Kircher and His American Readers." Athanasius Kircher. The Last Man Who Knew Everything. Paula Findlen, ed. Nueva York: Routledge, 2004. 329-64.

Flores Rangel, Juan José. Historia de México. México: Cengage Learning, 2003.

Godwin, Joscelyn. Athanasius Kircher. A Renaissance Man and the Quest for Lost Knowledge. Londres: Thames and Hudson, 1979.

Grossi, Verónica. “De la fiesta pública al claustro silencioso”. Bulletin of Spanish Studies 80/6 (2003): 665-93.

Sigilosos v(u)elos epistemológicos en sor Juana Inés de la Cruz. Madrid: Iberoamericana; Frankfurt: Vervuert, 2007.

López Poza, Sagrario. "La erudición de sor Juana Inés de la Cruz en el Neptuno alegórico". La Perinola 7 (2003): 241-65.

Mariscal, Beatriz. "Entre los juncos, entre las cañas: los indios en la fiesta jesuita novohispanoa”. Anales de literatura española 13 (1999): 51-62.

Martin, Vincent. El concepto de "representación" en los autos sacramentales de Calderón. Pamplona: Universidad de Navarra; Kassel: Reichenberger, 2002.

"El Neptuno de sor Juana: una prestidigitación alegórica de letras”. Aproximaciones a sor Juana. Sandra Lorenzano, ed. México: Fondo de Cultura EconómicaUniversidad del Claustro de sor Juana, 2005. 165-74.

Morales Folguera, José Miguel. "Mitología y emblemática en el arte efímero”. La producción simbólica en la América colonial. José Pascual Buxó, ed. México: UNAM, 2001. 285-95.

Orozco, Fernando. Gobernantes de México: desde la época prehispánica hasta nuestros días. México: Panorama, 2004.

Osorio Romero, Ignacio. La luz imaginaria: epistolario de Atanasio Kircher con los novohispanos. México: UNAM, 1993.

Pascual Buxó, José. El resplandor intelectual de las imágenes. Estudios de emblemática y literatura novohispana. México: Oak, 2001.

Paz, Octavio. Sor Juana Inés de la Cruz, o las trampas de la fe. México: Fondo de Cultura Económica, 1995.

Regalado, Antonio. Calderón. Los orígenes de la modernidad en la España del Siglo de Oro II. Barcelona: Destino, 1995.

Rodríguez de la Flor, Fernando. Teatro de la memoria: siete ensayos sobre mnemotecnia española de los siglos XVII y XVIII. Salamanca: Junta de Castilla y León, 1988.

Emblemas. Lecturas de la imagen simbólica. Madrid: Alianza, 1995.

Rodríguez-Sala, María Luisa. Letrados y técnicos de los siglos XVI y XVII. Escenarios y personajes en la construcción de la actividad científica y técnica novohispana. México: UNAM, 2002.

Sabat de Rivers, Georgina. "El Neptuno de Sor Juana: Fiesta barroca y programa político”. The University of Dayton Review 16/2 (1983): 63-73.

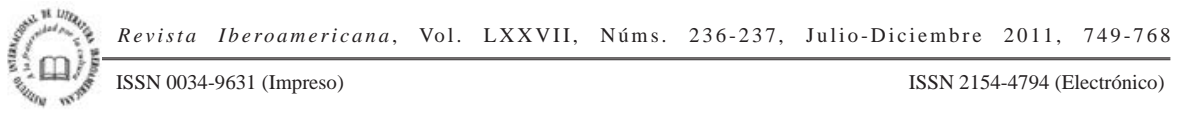


Serés, Guillermo. “El concepto de fantasía desde la estética clásica a la dieciochesca”. Anales de Literatura Española 10 (1994): 207-36.

Trabulse, Elías. "El silencio final de sor Juana.” Sor Juana y Vieira, trescientos años después. K. Josu Bijuesca, Pablo J. Brescia y Alejandro Rivas, eds. Santa Barbara: U of California P, 1998. 143-55.

Vermeir, Koen. “Athanasius Kircher’s Magical Instruments: An Essay on 'Science', 'Religion' and Applied Metaphysics.” Studies in History and Philosophy of Science 38/2 (2007): 363-400.

Yates, Frances A. Giordano Bruno y la tradición hermética. Barcelona: Ariel, 1983. El arte de la memoria. Madrid: Siruela, 2005. 